\title{
Indigenous and traditional knowledge, sustainable harvest, and the long road ahead to reach the 2020 Global Strategy for Plant Conservation objectives
}

\author{
Natalia Hanazaki ${ }^{1,4}$, Sofia Zank ${ }^{1}$, Viviane Stern Fonseca-Kruel ${ }^{2}$ \& Isabel Belloni Schmidt ${ }^{3}$
}

\begin{abstract}
Global strategies under the scope of CBD are important in guiding policies and resources for the conservation of biological diversity. This paper emphasized the need to develop actions under the Global Strategy for Plant Conservation (GSPC) with measurable results up to 2020, regarding the status and perspectives related to Targets 12 and 13, focusing on the Brazilian context in order to identify gaps and actions to achieve the goals for conservation and sustainable use of plants. It should be noted that Target 12 also covers logging, not necessarily directly related to indigenous peoples and traditional communities, but may threaten their livelihoods. In Brazil, scientific knowledge about the ecological effects of the harvesting of non-timber forest products is still limited, and few studies have contributed to the establishment of legal regulations for collection and management. With regard to target 13 , which concerns traditional and indigenous knowledge about plant use and the dependence of these peoples on plants, there are still a lack of integrative and effective policy initiatives. However, considering the negative political context of recent decades and exacerbated in recent years in relation to biodiversity conservation and indigenous peoples and local communities, profound changes are necessary in the Brazilian scenario, with strong support and recognition for indigenous peoples and local communities, so that any objective related to the achievement of the goals of the GSPC is minimally achieved. Key words: ethnobotany, harvesting, IPLC, NTFP, TEK.
\end{abstract}

\section{Resumo}

As estratégias globais no âmbito da CDB são importantes para orientar políticas e recursos para a conservação da diversidade biológica. Este artigo enfatizou a necessidade de desenvolver ações no âmbito da Estratégia Global para a Conservação de Plantas (GSPC) com resultados mensuráveis até 2020, no que se refere ao status e as perspectivas relacionadas às metas $12 \mathrm{e}$ 13, com foco no contexto brasileiro, visando identificar lacunas e ações para alcançar os objetivos para conservação e o uso sustentável das plantas. Salienta-se que a meta 12 abrange também a exploração madeireira, não necessariamente de relação direta com povos indígenas e comunidades tradicionais, porém pode vir a ameaçar seus meios de subsistência. No Brasil, o conhecimento científico sobre os efeitos ecológicos da coleta de produtos florestais não madeireiros ainda é limitado e poucos estudos contribuíram para o estabelecimento de regulamentações legais para coleta e manejo. Com relação à meta 13, que diz respeito aos conhecimentos tradicionais e indígenas sobre o uso de plantas e à dependência desses povos pelas plantas, ainda faltam iniciativas de políticas integradoras e eficazes. No entanto, considerando o contexto político negativo das últimas décadas e exacerbado nos últimos anos, em relação à conservação da biodiversidade e aos povos indígenas e comunidades locais são necessárias mudanças profundas no cenário brasileiro, com forte apoio e reconhecimento para os povos indígenas e comunidades locais, para que qualquer objetivo relacionado ao alcance das metas da GSPC seja minimamente perseguido.

Palavras-chave: etnobotânica, extrativismo, IPLC, NTFP, TEK.

\section{Introduction}

Global strategies under the scope of the Convention on Biological Diversity (CDB) are of paramount importance in guiding policies and resources toward conservation of biological diversity. The Global Strategy for Plant Conservation (GSPC) was proposed in 2002 and updated in 2010, aiming to decelerate global plant extinction through 16 global targets for the period 2011-2020 (CBD 2010a; Teixido et al. 2017). The updated version

\footnotetext{
${ }^{1}$ Universidade Federal de Santa Catarina, Centro de Ciências Biológicas, Lab. Ecologia Humana e Etnobotânica, Campus Trindade s/n, 88010-970, Florianópolis, SC, Brazil.

${ }^{2}$ Instituto de Pesquisas Jardim Botânico do Rio de Janeiro, R. Pacheco Leão 915, 22460-030, Rio de Janeiro, RJ, Brazil.

${ }^{3}$ Universidade de Brasília, Instituto de Ciências Biológicas, Depto. Ecologia, Campus Universitário Darcy Ribeiro, 70910-900, Brasília, DF, Brazil.

${ }^{4}$ Autor para correspondência: natalia.hanazaki@ufsc.br
} 
emphasizes the need to develop actions based on species and habitats, considering both natural and managed landscapes. These actions are targeted at specific and measurable results by 2020, as well as actions in the field of sustainable use of plant genetic resources related to human subsistence (Sharrock \& Wyse Jackson 2017).

The threats often linked to global plant extinction include habitat loss and fragmentation, overexploitation, invasive species, pollution, climatic change, and co-extinction (through cascading effects and domino effects among pollinators and plants), as well as the synergic effects between these threats (Krupnick 2013). In the Brazilian context, special emphasis is placed on habitat loss and fragmentation due to land use conversion for large-scale agriculture and pastures, mining activities, hydroelectric dams, infrastructure development, large uncontrolled wildfires, and overexploitation (Martins et al. 2017). Such large-scale pressures also threaten traditional peoples who depend on biodiversity for their livelihood and cultural identity. Additionally, these groups suffer from the loss or erosion of local systems of knowledge and management of plant resources due to rapid socioeconomic changes. The decoupling of lifestyles from the local environment has, for many, eroded their sense of place, language and indigenous and local knowledge (IPBES 2018).

Brazil is the most biodiverse country in the world, with more than 46,578 native plant species identified (Flora do Brasil 2020), and with a cultural diversity with more than 255 indigenous communities who speak 154 languages and dialects (ISA 2018), more than 3000 quilombos (Fundação Cultural Palmares 2018), and thousands of traditional communities who have known and managed biodiversity and landscapes for centuries, or even thousands of years. However, despite this biological and cultural richness, both the flora and the knowledge of the traditional peoples associated with biodiversity are little known, valued, or protected (Sobral \& Stehmann 2009).

Among the 16 GSPC objectives, the objective related to sustainable use in the updated version of GSPC emphasizes the use of plant diversity in a sustainable and equitable manner, and comprises three targets: Target 11, to refrain from the international trade of wild flora; Target 12, which refers to sustainable harvesting; and Target 13, which refers to indigenous knowledge associated with plant resources (CBD 2010a).
In this paper, we analyze the status and perspectives related to Targets 12 and 13, focusing on the Brazilian context. We do not intend to make a deep and complete revision of the subject, but rather intend to point out some opportunities for the fulfillment of global objectives for the conservation of plants related to sustainable use.

\section{Material and Methods}

To build an analysis of the status and perspectives related to Targets 12 and 13 in Brazil we reviewed the literature and consulted specialists in the area. This review was not intended to be exhaustive, but to provide an overview of these targets in the current Brazilian context. In this way, the compilation of ideas and perspectives presented here obviously reflect the view and experience of the authors on the subject. Although these two targets are components of the same objective, it is necessary to clarify the differences and articulations between them. "Sustainable harvest" refers to a broad set of activities, which can be done by, but are not restricted to, indigenous and traditional peoples. For example, several authors have analyzed the effects of logging, but primarily as results of activity that occurred with no clear relation to indigenous people and local communities (IPLC), both in the Amazon (Vidal et al. 2016), (Carvalho et al. 2017) and in subtropical forests (Souza et al. 2012). Logging activities can exclude IPLC and even threaten their livelihoods (Rist et al. 2012). Moreover, indigenous and traditional knowledge associated with plant resources go beyond wild plant harvesting and encompass the full gradient between domesticated, semi-domesticated, incipiently domesticated, and wild plants (Clement 1999) and animals, as well as the complex association between human management and landscapes (see for example Balée 2010; Machado Mello \& Peroni 2015).

The information on the Targets was organized through: i) an overview of the Targets 12 and 13; ii) Initiatives and challenges in implementation of these Targets in Brazil and other countries; iii) public and strategic policies to reach the Targets; and iv) recommendations for post-2020 targets.

\section{Results and Discussion}

Sustainable production and use of plant diversity: an overview of Target 12

According to Target 12 of the GSPC, until 2020, all wild harvested plant-based products 
must be sourced sustainably to avoid the risks of overexploitation, habitat loss, and decline in wild plant populations (CBD 2010a). This target increases the former mark of $30 \%$ of all plant-based products derived from sources that are sustainably managed until 2010, to all plant-based products derived from sources that are sustainably managed until 2020.

There is a wide range of situations in which harvesting of wild plants can occur: from smallscale subsistence harvesting to provide food, fuel, medicines, fibers, and timber, to a large demand for wild plants and products in the global market related to food, cosmetics, medicines, and materials (CBD 2010a; Saha \& Sundriyal 2012). Target 12 includes both timber and non-timber forest plant products (NTFP). Overharvesting of wild plant species can have serious consequences on both the plant populations and the livelihoods of the people these plants support (Krupnick 2013). However, overharvesting and sustainable production are not easy or straightforward concepts. These concepts deal with a wide array of activities that generate different impacts on plant populations and ecosystems.

The impacts of logging for timber vary depending on the harvest methods, including unplanned or predatory logging, conventional selective logging, and reduced-impact logging (with different logging intensities) (Rist et al. 2012). The forest management system in operation also varies, and the combination of these characteristics can have different shortcomings in the relation between logging and NTFP harvests (Guarigata et al. 2010; Rist et al. 2012). However, conflict of use and the indirect impacts of logging are most commonly implicated in negative effects on livelihood-relevant NTFPs (Rist et al. 2012).

For some tree species, such as big-leaf mahogany (Swietenia macrophylla King), there is evidence of the long-term unsustainability of harvesting (Free et al. 2013; Grogan \& Loveless, 2013). In other cases, such as the Brazil nut (Bertholletia excelsa Bonpl.), non-intensive harvesting is not a threat to the species at local or landscape scales (Ribeiro et al. 2014) and can be part of a socioecological system dependent on the continuous forest cover (Guarigata et al. 2017). However, there are potential problems in the harvesting of this species in flooded areas, due to climate change (Herraiz et al. 2017). Climate changes can also compromise harvesting in other biomes, such as for firewood harvesting in Caatinga (Althoff et al. 2016).
NTFP harvest can affect different ecological processes, but the majority of research is focused at a population level and on a limited subset of plant parts that are harvested (Ticktin 2004). Depending on the life form of the species harvested, harvesting intensity, plant part collected, and size of harvested individuals, harvest can result in different impacts in the structure and dynamics of the populations (Schmidt et al. 2011). According to Ticktin (2004), tolerance to harvest varies according to life history and the part of the plant that is harvested. For example, when analyzing matrix population models of 46 NTFP species, Schmidt et al. (2011) found that whole-plant harvest of perennial herbs and bark harvest from trees were not sustainable, resulting in decreased individual survival and population growth rates, whereas the harvest of palm leaves or fruits and rattan stems were potentially sustainable. Intensity, frequency of extraction, spatial scale, and purpose of harvest will also lead to different implications for sustainability (Ticktin 2004; Rist et al. 2012).

Additionally, economic sustainability may also be considered, including whether extractive returns meet the financial needs of harvesters (Stanley et al. 2012). As mentioned above, the very concept of "wild plant" carries nuances from species incipiently domesticated to wild ones (Clement 1999). When assuming these nuances, we include the management component over time to shape the current plant populations, and the conservation and sustainable extraction of such species cannot be disconnected from the people who manage them, as well as the aims and scale of the management performed.

Target 12 relates directly to Target 13 in situations where harvesting is done by IPLC. It also relates to Target 11, which focuses on eliminating the threat of international trade in wild plant species, including timbers, medicinal plants, and ornamental plants. The whole objective of use of plant diversity in a sustainable and equitable manner is connected to the GSPC objective of effective conservation of plant diversity, especially in in situ contexts. Also, Target 12 is directly linked to targets 4 and 5 of the Aichi targets of the Strategic Plan for Biodiversity 2011-2020 that focus on sustainable production and consumption within safe ecological limits and in management and sustainable harvesting of aquatic plants and fish stocks within safe ecological limits, respectively (CDB 2012). 
Indigenous and local knowledge, innovations, and practices related to plant resources

Target 13 refers to respecting and ensuring the valorization and perpetuation of knowledge and practices of IPLC associated with plant biodiversity. This knowledge about the environment is encompassed by traditional ecological knowledge (TEK) and local ecological knowledge (LEK). Traditional or local ecological knowledge is defined as a cumulative body of knowledge, practices, and beliefs that evolves through adaptive processes and is shared across generations through cultural transmission, including the relation of living beings (including humans) with each other and the environment (Berkes et al. 2000). The target explicitly addresses the goal to maintain or increase indigenous and local knowledge innovations and practices associated with plant resources to support customary use, sustainable livelihoods, and local food security (CBD 2010a).

TEK tends to be collectively owned and takes the form of cultural values, beliefs, rituals, consuetudinary arrangements, the local language, and management practices, among other manifestations (Berkes et al. 2000). Traditional knowledge, based on people's relationships with each other and with the environment, plays a key role in the development of sustainable livelihoods, support for food security, and promotion of the health and well-being of IPLC.

Numerous IPLC are situated in areas with high biodiversity. These IPLC have managed and used biological diversity for thousands of years and continue to do so today. The threat of extinction, widely known in the context of biodiversity, also occurs in the context of cultural diversity since these systems are coupled and interdependent (UNESCO/UNEP 2002). Concern over the loss of traditional knowledge is the driving force behind many ongoing ethnobotanical projects around the world (Oliveira et al. 2009; LagosWitte et al. 2011), reinforcing the importance of the connections between IPLC knowledge and practices and biodiversity conservation.

Target 13 is closely related to Article $8 \mathrm{j}$ of the CBD. According to this article, the signatory parties, as far as possible and, when appropriate, must comply with the respect, conservation and maintenance of knowledge, innovations and practices of IPLC with traditional lifestyles "relevant for the conservation and sustainable use of biological diversity and promote their wider application with the approval and involvement of the holders of such knowledge, innovations and practices and encourage the equitable sharing of the benefits arising from the utilization of such knowledge, innovations and practices" (CBD 2010a). Article 8j of the CBD also supports other, broader objectives and targets. The implementation of GPSC Target 13 is related to the Aichi Biodiversity targets, especially in Target 18: "By 2020, the traditional knowledge, innovations, and practices of indigenous and local communities relevant for the conservation and sustainable use of biodiversity, and their customary use of biological resources, are respected, subject to national legislation and relevant international obligations, and fully integrated and reflected in the implementation of the Convention with the full and effective participation of indigenous and local communities, at all relevant levels" (CBD 2010b). This Target also connects with Aichi Target 16, which deals with access to genetic resources and fair benefit sharing, assuming that by 2015, "the Nagoya Protocol on Access to Genetic Resources and the Fair and Equitable Sharing of Benefits Arising from their Utilization is in force and operational, consistent with national legislation."

Initiatives and challenges:

Harvesting of wild plant-based products

Wild plant-based resources can be harvested in a wide array of intensities, from large-scale, destructive forest logging to small-scale NTFP harvesting, and several variations in between. Thus, any status assessment of such a diverse array of activities can be only partial. The complex issue of identifying the sustainability of harvesting wild plant-based products is also affected by this wide array of activities. The sustainability of harvesting wild plant-based products can be based primarily on maintaining population viability of the species and supplying adequate incomes and is not restricted to the economic production of timber volumes and sustaining timber stands.

While most studies, and even some public policies, are focused on the population or species level, larger regional public policies may also be applicable. This is especially relevant to timber, for which harvesting is not species-specific. For example, the regulations for forest management in the Amazon basin are based on parameters like growth-oriented logging (Schöngart 2008), and policies toward timber concessions can consider 
different types and scales of timber harvesting, including community-based timber extraction. However, such initiatives are criticized when considering, for example, simple ecological variables, such as tree density (da Silva-Marinho et al. 2010) or structural problems within the industry and the government itself (Azevedo-Ramos et al. 2015; Finer et al. 2014).

Even if ecological parameters used to implement such policies are simplistic-due to both the lack of detailed information or feasibility of more detailed regulations-regulating timber production based on forest management plans is an important step to increase this type of timber operation as opposed to forest clearcutting and land use conversion. More than $80 \%$ of the timber production in Brazil uses illegal deforestation activities, and the official information regarding timber production in very limited. For example, the National System on Forest Information indicates that São Paulo state produces and exports more timber (from planted exotic forests) than all the Amazon basin states combined (IBGE 2015).

Officially, the exotic silviculture timber production in Brazil is five times larger than native timber production (IBGE 2015). This is unlikely to reflect the reality since large areas of native forest, rich in valuable timber, are illegally deforested every year (according to Greenpeace et al. 2017, only in Amazon between 1990 and 2000 an average of 18.6 thousand $\mathrm{km}^{2}$ was deforested per year, which increased to 19.1 thousand $\mathrm{km} 2$ between 2000 and 2010; in 2017 the total area deforested accounts for $780,000 \mathrm{~km}^{2}$ ). The scale of the illegal timber commerce can be estimated from the fact that, between 2000 and 2012, 68\%-90\% of forest clearing in Brazil was illegal (Lawson et al. 2014).

As in many other regions (Ticktin 2004), studies and public policies related to plant harvesting are specific and established in local or regional scales. In Brazil, there is limited scientific knowledge on the ecological effects of NTFP harvesting, and few studies have led or contributed to the establishment of legal harvesting or management regulations. Some illustrative examples are discussed here, although there are several other initiatives in progress. In the Amazon, the harvesting of tree individuals or branches of Aniba rosiodora Ducke, a threatened tree species listed in Appendix II of CITES, is regulated by a Brazilian Environmental Agency norm (IBAMA IN 09/2010). This regulation establishes that $A$. rosiodora trees can only be exploited in areas where all trees with diameter at breast height (DAP) above $10 \mathrm{~cm}$ have been measured, and only $66 \%$ of the trees with DAP $25 \mathrm{~cm}$ can be cut from these areas annually. The regulation also determines that 80 A. rosiodora seedlings should be planted for every $180 \mathrm{~kg}$ of essential oil extracted. Furthermore, the regulation also indicates the possibility of using the tree branches to extract the essential oil that is exported to the European cosmetic industry at a high price.

In the southern states of Santa Catarina and Paraná, the harvest of Araucaria angustifolia (Bertol.) Kuntze, an endangered tree species, is protected from logging by federal law $(11,428 / 2006)$. The seeds, highly valued in the regional market for food (pinhão), can only be harvested after April 1 ${ }^{\text {st}}$, and there are fiscal incentives for private properties that conserve or cultivate this species. Several other endangered, ecologically, or culturally important tree species are protected from logging in Brazil, such as Bertholetia excelsa (legally protected since the Forest Code in 1965 and more recent and specifically in some state legislation, for example, Pará state law 6,895/2006); Caryocar brasiliense Cambess. in Minas Gerais, Mato Grosso, Mato Grosso do Sul, Goiás, and Tocantins; Ficus spp.; Erythrina crista-galli L.; Prosopis spp.; and the palm Butia capitata (Mart.) Becc. in Rio Grande do Sul. However, protecting specific species from cutting does not guarantee the species' conservation, since even if NTFP harvesting may impact populations, higher threats are posed by land use changes (e.g., Peres et al. 2003). Such regulations often lead to the sight of a single tree standing in pasturelands, which is common in the case of $B$. excelsa in pasturelands in the Amazon or C. brasiliense in extensive Eucalyptus spp. plantations in the Cerrado.

There is at least one instance in which a prohibition on cutting benefits species conservation and, especially, local livelihoods that depend on NTFP products. State and municipality laws in Maranhão, Piauí, Pará, and Tocantins states prevent the cutting of Attalea speciosa Mart. ex Spreng. individuals, and states that local harvesters should be granted free access to harvesting areas to obtain the palm fruit used for oil, handicrafts, and fuel by around 300,000 of babaçu nut harvesters (Quebradeiras de coco), organized through a women's interstate community-based movement who have defended harvesters' rights for decades (Rego \& Andrade 2006; Araujo Jr. et al. 2014). 
Very few ecological studies have addressed the LEK and the ecological impacts of NTFP harvesting in Brazil, and even fewer have led to legal harvesting regulations. An emblematic example of such cases comes from the Cerrado region, where the flower stalks of Syngonanthus nitens Ruhland, harvested for handicrafts, have become the most important source of income for hundreds of local families. Based on LEK and ecological experiments, the species harvesting has been regulated since 2004 (Tocantins state Law $362 / 2007)$. Flower stalks can only be harvested after September $20^{\text {th }}$, and plants' capitulum (fruits) need to be cut and dispersed in the humid grasslands where the species occur, just after harvesting (Schmidt \& Ticktin 2012). Detailed studies and recommendations for sustainable harvesting regulations that combine LEK and ecological parameters have been proposed for other species, such as Himatanthus drasticus (Mart.) Plumel latex (Baldauf et al. 2014) and for the fern Rumohra adiantiformis (G. Forst) Ching (Baldaulf et al. 2007). It is important to point out that harvesting regulations can only be beneficial to local communities and to sustainable use if they are developed and implemented in cooperation with local communities (Schmidt \& Ticktin 2012). Such regulations should focus in avoiding overexploitation by economically-driven interests, especially those that exclude local communities from harvesting processes to due increase legal and/or technological requirements (Godoy \& Bawa 1993). All the examples cited above followed these principles and seek to insure harvesters access to products local communities rights to harvest native plants according to sustainable principles.

The official information on harvesting of NTFP is limited and is mostly concentrated on a small number of products and species from the Amazon basin. For example, the latest national inventory on species harvesting provides information on fewer than 20 native species, has limited information, and can be imprecise regarding the species harvested (IBGE 2015). All the species are listed by common names, which may represent more than one species in the same genus or even several species, both threatened and unthreatened. Most of the NTFP sales in Brazil are informal (as is almost $40 \%$ of the country's economy). Therefore, these official data are rather limited and unlikely to represent reality. For example, the national inventory indicates that 216,000 tons of açaí palm (Euterpe oleracea Mart.) fruit had been sold in the whole country (Amazon basin) in 2014, whereas a state level inventory from Pará state almost ten years earlier indicates that more than 150,000 tons had been sold (Bolsa Verde, Pará, 2005).

Public policies focused on the sustainable use and income generation from biodiversity are spread throughout the three governmental levels: federal, state, and municipality. Within the federal government, the Ministry of the Environment has a specific sector - the Secretariat of Harvesting and Sustainable Rural Development (Secretaria de Extrativismo e Desenvolvimento Rural Sustentável, or SEDR)_-devoted to these subjects. This secretariat deals with policies, strategies, and promotion of studies aimed to support and promote the sustainable development of harvesting communities and trades, addressing topics such as management, environmental territorial planning, and productive chains based on resources from socio-biodiversity and development of products and processes derived from genetic resources of biodiversity (MMA 2011). This secretariat also coordinates the elaboration of the Economic Ecological Zoning and promotes the adoption of sustainable technologies, especially in agriculture, harvesting, and local agroindustry and their production chains, also dealing with agendas related to avoiding deforestation, forest conservation, and public policies targeted to IPLC (MMA 2011). With these ample agendas, at the federal level, the Ministry can rarely achieve on the ground results with practical implications for the sustainable harvest of native plants.

In some instances, however, the Ministry actions result in practical outcomes to native plant harvesters. For example, SEDR has partnered with other ministries and sectors, such as the Ministry of Agrarian Development, Ministry of Social Development, and the National Supply Company. Currently, the National Supply Company is developing a policy related to the products of sociobiodiversity through the Minimum Price Guarantee Policy for Socio-biodiversity Products (PGPMBio). When the price of the product is below the minimum established by the federal government, the Company pays the difference to encourage continuity of the extractive activity. According to CONAB (2016), PGPM-Bio guarantees the price of more than 15 extractive products and, in the last eight years, more than 34 million Reais (more than 10 million US dollars) were directed to the subsidy of products of socio-biodiversity of extractive origin, harvested directly from the forest: 
açaí (E.oleracea and less frequently E. precatoria Mart.), andiroba (Carapa guianensis Aubl.), babaçu (Attalea speciosa Mart. ex Spreng.), baru (Dipteryx alata Vogel), rubber (Hevea brasiliensis (Willd. ex A.Juss.) Müll), cacao (Theobroma cacao L.), brazil nuts (B. excelsa), carnaúba (Copernicia prunifera (Mill.) H.E.Moore), juçara (Euterpe edulis Mart.), macaúba (Acrocomia aculeata (Jacq.) Lodd. ex Mart.), mangaba (Hancornia speciosa Gomes), pequi (C. brasiliense), piaçava (Attalea funifera Mart., Leopoldinia piassaba Wallace), pinhão (A.angustifolia) and umbu (Spondias tuberosa Arruda).

Although such policies may help the sustainable harvest and improve local livelihoods, they are incipient and extremely concentrated in the Amazon region. Also, substantial changes have taken place within the scope of the Ministries and their attributions, which makes the issues of production, harvesting, and related public policies even more complex. For example, the Ministry of Agrarian Development (MDA), which is different from the Ministry of Agriculture (MAPA), is in charge of the management of public policies to stimulate agriculture and agribusiness. The MDA had competences to work on several issues, such as agrarian reform and agrarian reordering, land regularization in the Legal Amazon, promotion of sustainable development in agriculture and rural areas, and the identification, recognition, delimitation, demarcation, and titling of lands occupied by the remnants of communities of the quilombos. In 2016, some of these competences were transferred to other Secretaries and thus subordinated the structure of the defunct MDA to the Minister of State Chief of Staff of the Presidency of the Republic, limiting and/or extinguishing several of the former MDA policies and attributions. In addition to these specific changes in MDA, several other policies and programs targeted to agriculture and traditional peoples, and several other minority groups, have been cut or extinguished since 2016 threatening the conservation of native habitats, territorial rights and the human rights of diverse social groups (Carneiro da Cunha 2017).

Other interesting possibilities that link harvesting and IPLC are, for example, the Brazilian Quilombos Seal and the Brazilian Indigenous Seal. The Brazilian Indigenous Seal, which identifies the product's origin, is a collaborative initiative by MDA, the Ministry of Justice, and the National Indian Foundation. This seal promotes the ethnic and territorial identification of indigenous products and meets a historical demand by indigenous peoples to expand their productive inclusion, contribute to food and nutritional sovereignty, and improve the quality of life and income generation. In 2015, the first seal was given to the Kiriri and Kaingang indigenous producers. This brand can be found on packages of biscuits and products derived from cassava and produced by the Kiriri people in Northeastern Brazil, and in products from the Cooperative of Family Farmers of Tenente Portela, constituted of Kaingang farmers in Rio Grande do Sul (Casa Civil 2015). However, these are still limited initiatives, considering that there are more than 200 indigenous peoples in Brazil.

Initiatives and challenges:

IPLC and plant resources

The implementation of Target 13 at the international level is connected to Article $8 \mathrm{j}$ of the CBD. In this context, a TEK knowledge information portal (CBD 2018) was created to promote awareness and stimulate dialogue, increasing the visibility of IPLC and encouraging the exchange of information. This portal does not provide or document traditional knowledge per se but addresses important information about and for traditional knowledge. Also, workshops are held to strengthen the capacity of representatives of indigenous and local communities on traditional knowledge and customary sustainable use (CBD 2018).

At the international level, the Global Diversity Foundation (GDF) can be considered as another initiative contributing to this target. This non-profit organization is a family of regional organizations and initiatives that promote biocultural diversity through training, documentation, and networking opportunities. Also, the GDF has used collaborative research initiatives with indigenous communities in Mesoamerica, North Africa, Southeast Asia, and southern Africa, providing training and support to communities as they design and implement their own initiatives to conserve local environments and improve their means of subsistence and well-being (GDF 2018). Other international and regional institutions have applied and recommended tools for the protection of traditional knowledge, such as community protocols, a geographical indication of biodiversity products, access, benefit sharing partnerships, and a community biodiversity registry (Swiderska et al. 2009; Chiarolla \& Lapeyre 2013).

Other examples of initiatives related to this target can be found in the international scenario. In India, the second largest exporter of medicinal 
plants, about $90 \%$ of the medicinal plants used by the country's health industry are harvested in the wild, and 315 of the 6560 known medicinal species are threatened by extinction (Ministry of Environment and Forests of India 2014). Initiatives, such as the People's Biodiversity Registers that include medicinal plants, were implemented after the Biological Diversity Act of 2002 was adopted as a national policy. The United Nations Development Program, together with the Ministry of Forestry and Food, encourages healers to document the medicinal plants used and the treatment offered, in the hope that traditional local knowledge will not be lost. This tool allows the community itself to be responsible for recording and safeguarding their knowledge (Gadgil 2006).

High on the Andes, where Quechua communities grow hundreds of varieties of potatoes, an agreement has been developed for benefit sharing and conservation of the unique biocultural system of Potato Park. The Community Protocols were very important in this process, as they provided communities a vital pathway for the negotiation of equitable agreements and the conservation of their local biodiversity and traditional knowledge. These protocols establish the rights and responsibilities of a community in relation to its natural resources and can set internal community rules for equitable sharing of benefits and the sustainable management of natural resources (Argumedo 2013). At the New York Botanical Garden, a group of traditional healers and conservationists from Belize worked to inventory and catalog the flora of Belize and associated ethnobotanical knowledge, from 1988 to the present. The most significant results of the project so far are a guide to the useful plants of Belize (Balick \& Arvigo 2015), a Belize flora checklist (Balick et al. 2000), and the establishment of an association of Belizean traditional healers, assisting in the development of a community of individuals dedicated to this practice.

Other initiatives include an expansion of the scientific development of ethnobotany, a field of research that studies the direct interrelationships between humans and plants in dynamic systems (Alcorn 1995). In both theoretical (Albuquerque et al. 2009; Gaoue et al. 2017; Conde et al. 2017) and applied approaches, ethnobotany can be used as a tool for conservation of natural resources and indigenous and local knowledge (Lagos-Witte 2011; Ulian et al. 2016; Missouri Botanical Garden 2018). We stress the importance of participatory action research processes (Argumedo 2012, 2013), which are important in stimulating a sense of pride in traditional knowledge as this knowledge has been systematically devalued by external actors and is rapidly being lost, along with biodiversity.

In Brazil, there were few institutional advances in the implementation of this target. As an example, we can mention the initiatives of research centers in ethnobotany, botanical gardens, nongovernmental organizations (NGOs), and public policies related to access to traditional knowledge and benefit sharing. For example, some NGOs in Brazil have been working for decades to fund and encourage the sustainable use of biodiversity, starting from a focus on their intrinsic relationship with IPLC, such as the Institute for Society, Population, and Nature (ISPN) and Instituto Socioambiental (ISA).

Academic literature directly addressing the fulfillment of Target 13 in Brazil is almost nonexistent. However, at an academic level, ethnobotany has been growing as a field of research and teaching in Brazil (Fonseca-Kruel et al. 2005; Oliveira et al. 2009). Ethnobotanical research in recording knowledge and practices of indigenous and local peoples contributes to Target 13, and it is important to establish mechanisms for this knowledge to influence public policies toward the protection and safeguarding of biocultural heritage. An example of the academic initiative is discussed by Forzza et al. (2016), who highlight the actions of the Rio de Janeiro Botanical Garden to contribute to GSPC targets, in which the achievement of Target 13 benefits from the Ethnobotany Collection. The main objectives of this collection are to link the importance of both biological and cultural diversity, ensure the registration and preservation of knowledge related to the use of plants by people, including handcrafts, medicinal plants, and medicines marketed in Brazilian public markets, and to initiate a mapping of the useful plant resources of Brazil. Also, the collection relies on research in international historical collections for the repatriation of data on the history of plant use in Brazil (e.g., Spruce Collection from Economic Botany Collection - RBG/Kew to REFLORA platform).

In the scope of the research that accesses IPLC knowledge, and to protect such knowledge and practices, it is fundamental that researchers follow ethical and legal procedures related to access and benefit sharing. We emphasize the importance of Prior and Informed Consent, which must be carried out with the communities before the beginning of 
the research. These procedures are highlighted in International Labour Organization Convention 169, International Society for Ethnobiology Code of Ethics (ISE 2006), as well as in other conventions dealing with the rights of indigenous and local peoples (CBD 2012; Contreras et al. 2015); and from another perspective, Prior Informed Consent is also supported by discussions on research with human beings as a whole. Ethical issues about access to IPLC knowledge in Brazil were discussed by Liporacci et al. (2015) and Pedrollo \& Kinupp (2015), showing fragilities and limitations of the procedures in operation from 2002 until 2015 under the guidelines of the provisional measure which was valid during those dates. The new regulations, framed by Law 13,123/2015, still appear to be of limited effectiveness in protecting the traditional knowledge associated with biodiversity (Moreira \& Conde 2017); where access to associated traditional knowledge of identifiable origin is conditional on obtaining prior informed consent and associated traditional knowledge of non-identifiable origin (e.g., diffuse knowledge) is independent of prior informed consent .

\section{Public policies and strategies}

to reach the targets

Despite efforts at various scales generated by the GSPC, greater progress is being made in public policies and actions to meet the demand for knowledge and conservation of plants, with red lists and some action plans for endangered plants, which relate to Objective I (Martins et al. 2017). At the national level, there are still no coordinated policies to meet the third GSPC objective, related to the sustainable and equitable use of plant species diversity, and especially to meet Targets 12 and 13. Target 12 needs to consider the several scales of harvesting, use, and commercialization, and to include all wild harvested plant-based products that must be sourced sustainably. According to CBD (2010a), Target 13 aims to "maintain or increase, as appropriate, innovations and practices associated with plant resources to support customary use, sustainable livelihoods, local food security and health care" (our emphasis). The lack of coordinated policies is is also reflected in the literature, such as Martins et al. (2017), which deals with the challenges and perspectives for achieving the GSPC targets in Brazil, where only the following goals were treated as challenges for Brazil: Target 1 (an online flora of all known plants), Target 2 (an assessment of the conservation status of all known plant species, as far as possible, to guide conservation actions), Target 3 (information, research and associated outputs, and methods necessary to implement, develop, and share the strategy), Target 7 (at least 75\% of known threatened plant species conserved in situ), Target 8 (at least $75 \%$ of threatened plant species in ex situ collections, preferably in the country of origin, and at least $20 \%$ available for recovery and restoration programs), Target 15 (the number of trained people working with appropriate facilities sufficient, according to national needs, to achieve the targets of this strategy), and Target 16 (institutions, networks, and partnerships for plant conservation established or strengthened at national, regional, and international levels to achieve the targets of this strategy). A similar approach is found in the document describing the progress in implementing the GSPC in Brazil, provided to the CBD Secretariat following the GSPC Liaison Group meeting held in July 2011, which skips GSPC Targets 5, 6, 9, 10, 11, 12, 13, and $14(<\mathrm{https}: / /$ www.cbd.int/doc/meetings/pc/ gspclg-04/other/gspclg-04-submission-brazil2011-171-en.pdf $>$ ).

According to Sharrock \& Wyse Jackson (2017), although the goals of the GSPC have been important in stimulating individual institutional actions and leading the conservation objectives of plants, few Parties have developed national responses to GSPC in the form of strategies for plant conservation or the development of national targets. Brazil, as well as most Parties, have sought to achieve plant conservation within the context of their National Biodiversity Strategies and Action Plans. There is a continuing lack of integration of plant conservation policies at the national level, just as the broader debate on biodiversity, sociodiversity, and sustainability has been neglected. This debate is urgent in Brazil because the diversity of wild plants used sustainably, as in the growing trade in "natural cosmetics," and perfumery, can provide a range of options for reducing poverty (e.g., babassu, carnauba, medicinal plants, açaí, and Brazil nuts, among others).

To ensure that the poor and the most vulnerable benefit from the use of wild plant resources, the Aichi Strategic Plan for Biodiversity and Biodiversity (CBD 2010b) has made progress in mainstreaming biodiversity concerns into broad social, economic, and development policies, reaffirming the links between human sustainability and plant conservation that may be the best option 
in the future. To this end, there is still a need to broaden the debate and integrate the discussions about issues such as land ownership, equitable and fair access to resources, and restrictive conservation measures vs. exclusion of local livelihoods based on plant resources.

Another sensitive, complex, and interconnected theme, apart from the sustainable use and equitable benefit sharing and conservation of plant resources, is protection for the IPLC, although there is a National Policy of Sustainable Development of the Peoples and Traditional Communities (Brasil 2007). Initiatives that were coordinated, for example, by the Ministry of Agrarian Development and supported by these legal frameworks, have suffered from the weakening and disruption of the Federal Constitution. Indigenous peoples, quilombolas, and local communities have lost many constitutional rights in the current federal government, for example, with the interruption in the quilombola lands titling processes. We are currently experiencing a weakening of federal agencies that have been performing their functions, albeit with difficulty, such as the National Institute of Colonization and Agrarian Reform and the National Indian Foundation, which closed local technical coordination and replaced or exonerated several employees. It is also important to stimulate public policies that assist indigenous peoples and local communities to document and safeguard traditional knowledge and practices so that they remain available to support sustainable use of plants. The rights to the indigenous territories must be guaranteed, since without them the production and transmission of traditional ecological knowledge associated with sustainable use is threatened.

Regarding national public policies related to Target 13, we highlight the legislation for access to traditional knowledge and fair and equitable benefit sharing (Law 13,123/2015 and Decree $8,772 / 2016)$. The process of creating these legal documents brought many criticisms in Brazil and elsewhere (e.g., Prathapan et al. 2018), due to the way the access to both genetic resources and traditional knowledge was regulated. In Brazil, the legislation violated the principle of prior and informed consultation of IPLC in the discussion of the law, which is the legislation that should protect knowledge, practices, and innovations. This violation was denounced by many organizations related to the IPLC and also by the Federal Public Ministry, before the law was published, in documents such as a Technical Note of the Public Ministry on the project 7735/2014 and the letter "De onde brotam os espinhos" (Where the thorns come from). On the one hand, this legislation has setbacks related to the rights of IPLC, for example, because prior informed consent in some access situations (traditional knowledge of non-identifiable origin) is not mandatory, and the various possibilities of exemption from benefit sharing may lead to distortions of the CBD statements and the international legal framework in general. Part of the Brazilian legislation criticism from local and traditional communities as well as researchers is centered on the important role pharmaceutical industry has played in the discussion to setting the regulations. On the other hand, this legislation has made progress by including and recognizing community protocols as a way of obtaining prior and informed consent, and by creating the possibility of a database that can be accessed by IPLC, as well as for the establishment of public policies for the protection of biocultural heritage.

Finally, another worrying issue is that Brazil has not yet ratified the Nagoya Protocol, adopted in 2010 and in force since 2014. With regard to associated traditional knowledge, the protocol means that the parties must take measures to ensure that access only occurs with the prior and informed consent of those communities and when the terms of fair and equitable sharing of benefits are agreed upon. Since the Nagoya Protocol was signed by Brazil but has not been ratified, it is not yet in force in our country. One of the main reasons for this and other setbacks in environmental policies in Brazil is the fact that the federal parliament has been dominated by agribusiness interests (bancada ruralista) with increased political power in the two past decades, that has worked to stop any environmental legislation, local and traditional communities rights as well as any limitations to deforestation, use of pesticides or climate change mitigation policies (Carneiro da Cunha 2017). These actors from agribusiness were also reluctant because they believed that by ratifying the Nagoya Protocol, Brazil would have to pay royalties for the production and sale of grains from other countries, such as soybeans, a fact that is untrue.

\section{Recommendations} for post-2020 targets

Even when recognizing the links between GSPC and the achievement of other related international goals (Sharrock \& Jackson 2017), we 
are very far from achieving the objective to use plant diversity in a sustainable and equitable manner. According to Solecki et al. (2017), we need to face a new era of global environmental sustainability understanding in which the challenges in achieving sustainable development goals requires attention to the "larger matrix of environments, resources, and people upon which urban populations depend" (Solecki et al. 2017), which requires changes in the "business as usual" scenario (IPBES 2018).

The role of IPLC in biodiversity conservation and human well-being is stressed by several authors (see for example Tëngo et al. 2017), and the need to change approaches toward the empowerment of local communities is not a new issue (Kohler \& Brondizio 2016; Chiarolla \& Lapeyre 2013). This needs to go way being empowerment in Brazil, where environmental and social leaderships are frequently threatened and killed for fighting for conservation, local communities territorial rights and social causes (Carneiro da Cunha 2017). Based on the examples of IPBES and CBD, Tëngo et al. (2017) argue that collaboration across knowledge systems will require moving from studies "into" or "about" indigenous and local knowledge systems to equitable engagement "with" and "among" these knowledge systems. This change of perspective also requires a stronger engagement of IPLC and other sectors of the society involved with extraction and harvesting plant resources to reach the sustainability goals as a whole. In particular, achieving these GSPC goals requires the effective involvement of several sectors, from state and social stakeholders and beyond scientific or academic studies.

At an international level, IPBES is directed to strengthen knowledge foundations for better policy through science and is comprised of conservation and sustainable use of biodiversity, as well as with human well-being (IPBES 2018). This initiative has sought to develop mechanisms that guarantee the effective integration and participation of IPLC in the improvement of the global governance of biodiversity and ecosystem services, with four interconnected functions: to catalyze the generation of new knowledge; to produce assessments of existing knowledge; to support the formulation and implementation of policies; and to build relevant capacities to achieve their goal (Díaz et al. 2015). As for recommendations for post-2020 targets, it is desirable to strengthen the Brazilian Platform on Biodiversity and Ecosystem Services (BPBES 2017), with an analogous mission to IPBES.
Other initiatives, more focused on the academic sphere, can be strengthened, such as the incentive for the establishment of biocultural collections; the organization and decentralization of national databases involving institutions representative of IPLC and favoring access to this knowledge by local people and local organizations; and encouraging community records of biodiversity. It is also suggested that the creation of capacity-building mechanisms at all levels (e.g., government, the private sector, academics, and local communities) will provide formal recognition of IPLC initiatives and the strengthening of their customary laws and rules. Regarding the harvesting of wild plant-based products on a local scale, the lack of scientific information should not prevent regulations being proposed and implemented with basis on local ecological knowledge and always avoiding regulations that exclude local communities and concentrate profits (Simoni et al. 2010). Regulations can be proposed based on TEK and technical knowledge from environmental managers and considered in an adaptive framework to improve regulations if needed. We need to reverse the squandering of our natural heritage. Thus, we need integrated policies that assess the economic importance of ecosystem services that are essential to human well-being. We need to change our predatory model of the last half millenium, to a development model that has our wealth in biodiversity and ecosystem services as one of its pillars.

We emphasize that recognition of the territory of IPLC is essential. The struggle of indigenous and local communities for the recognition of their land rights is crucially important since the conservation of biocultural heritage depends on the guarantee of their territorial spaces. Finally, a strong change in the current political scenario is urgent: although there were a few advances, currently we are failing on the journey through the long road ahead to achieve GSPC targets 12 and 13.

\section{Acknowledgements}

We thank to F. Silveira for the challenging invitation to compile information and write this article. Thanks to S. Romero, R. Q.Portela, C. Baldauf, R.Ramos, P.T.Sano, C.M.C.Mello, and C.R. Clement who provided useful information for some topics discussed here, and to criticisms and suggestions of the anonymous reviewers. $\mathrm{NH}$ thanks to $\mathrm{CNPq}$ for a research scholarship (309613/2015-9). 


\section{References}

Albuquerque UP, Sousa Araújo TA, Ramos MA, Nascimento VT, Lucena RFP, Monteiro JM, Alencar NL \& Lima Araújo E (2009) How ethnobotany can aid biodiversity conservation: reflections on investigations in the semi-arid region of NE Brazil. Biodiversity and Conservation 18: 127-150.

Alcorn JB (1995) The scope and aims of ethnobotany in a developing world. In: Schultes RE \& Reis SV (eds.) Ethnobotany: evolution of a discipline. Timber Press, Cambridge. Pp. 23-39.

Althoff TD, Menezes RSC, Carvalho AL, Siqueira Pinto A, Santiago GACF, Ometto JPHB, von Randow C \& Sá Barretto Sampaio EV (2016) Climate change impacts on the sustainability of the firewood harvest and vegetation and soil carbon stocks in a tropical dry forest in Santa Teresinha Municipality, Northeast Brazil. Forest Ecology and Management 360: 367-375.

Araujo Junior ME, Dmitruk EJ \& Moura JCC (2014) A lei do babaçu livre: uma estratégia para a regulamentação e a proteção da atividade das quebradeiras de coco no estado do Maranhão. Sequência 68: 129-157.

Argumedo A (2012) Decolonising action-research: the Potato Park biocultural protocol for benefitsharing. In: Swiderska K, Milligan A, Kohli K, Jonas H, Shrumm H, Hiemstra W \& Oliva MJ (eds.) Participatory Learning in Action 65. IIED, London. Pp. 91-100.

Argumedo A (2013) Collective trademarks and biocultural heritage: towards new indications of distinction for indigenous peoples in the Potato Park, Peru. IIED, London. Available at $<$ http://pubs.iied. org/16528IIED/>. Access on 11 April 2018.

Azevedo-Ramos C, Silva JNM \& Merry F (2015) The evolution of Brazilian forest concessions. Elementa Science of the Anthropocene 3: 48.

Baldauf C \& Santos FAM (2014) The effect of management systems and ecosystem types on bark regeneration in Himatanthus drasticus (Apocynaceae): Recommendations for sustainable harvesting. Environmental Monitoring and Assessment 186: 349-359.

BaldaufC, Reis MS \& Hanazaki N (2007) Ethnobotanical characterization of leatherleaf fern (Rumohra adiantiformis (G. Forst) Ching - Dryopteridaceae) management systems used in southern Brazil. Acta Botanica Brasilica 21: 823-834.

Balée W (2010) Contingent diversity on anthropic landscapes. Diversity 2: 163-181.

Balick MJ \& Arvigo R (2015) Messages from the gods: a guide to the useful plants of Belize. The New York Botanical Garden Press/Oxford University Press, New York. 560p.

Balick MJ, Nee MH \& Atha DE (2000) Checklist of the vascular plants of Belize with common names and uses. Memoirs of The New York Botanical Garden 85: 246.

Berkes F, Colding J \& Folke C (2000) Rediscovery of Traditional Ecological Knowledge as adaptive management. Ecological Applications 10: 12511262.

BPBES (2017) Plataforma Brasileira de Biodiversidade e Serviços Ecossistêmicos. Available at <https:// www.bpbes.net.br/> Access on 11 April 2018.

Brasil (2007) Decreto $n^{\circ} 6.040$, de 7 de fevereiro de 2007. Diário Oficial da República Federativa do Brasil, Brasília, DF, 07 de fevereiro de 2007. Disponível em <http://www.planalto.gov.br/ ccivil_03/ato2007-2010/2007/decreto/d6040. htm>. Access on 11 April 2018.

Carneiro da Cunha M (2017) Indigenous peoples boxed in by Brazil's political crisis. Introduction. Hau: Journal of Ethnographic Theory 7: 403-426.

Carvalho AL, d'Oliveira MVN, Putz FE \& de Oliveira LC (2017) Natural regeneration of trees in selectively logged forest in western Amazonia. Forest Ecology and Management 392: 36-44.

Casa Civil - Secretaria Especial de Agricultura Familiar e do Desenvolvimento Agrário (2015) Available at $<$ http://www.mda.gov.br/sitemda/tags/povos-ecomunidades-tradicionais $>$. Access on $28 \mathrm{March}$ 2018.

CBD - Convention on Biological Diversity (2010a) Updated Global Strategy for Plant Conservation 2011-2020. Available at <https://www.cbd.int/ gspc/> Access on 11 April 2018.

CBD - Convention on Biological Diversity (2010b) Strategic plan for biodiversity 2011-2020. Aichi Biodiversity Targets. Available at <https:/www. cbd.int/sp/targets/default.shtml $>$. Access on 11 April 2018.

CBD - Convention on Biological Diversity (2012) Tkarihwaié:ri: código de conducta ética para asegurar el respeto al patrimonio cultural e intelectual de las comunidades indígenas y locales pertinentes para la conservación y uso sostenible de la diversidad biológica. Secretaría del Convenio sobre la Diversidad Biológica. 16p. Available at <https://www.cbd.int/doc/ publications/ethicalconduct-brochure-es.pdf $>$. Access on 18 December 2017.

CBD - Convention on Biological Diversity (2018) Traditional knowledge information portal. Available at $<$ https://www.cbd.int/tk/ $>$. Access on 11 April 2018.

Chiarolla C \& Lapeyre R (2013) Biodiversity and traditional knowledge: how can they be protected? Policy Brief IDDRI, 13/2013. Available at $<$ https:/www.iddri.org/sites/default/files/import/ publications/pb1313_report-conf.-iddri-feh-bnf. pdf>. Access on 11 April 2018. 
Clement CR (1999) 1492 and the loss of Amazonian crop genetic resources. I. The relation between domestication and human population decline. Economic Botany 53: 188-202.

CONAB - Companhia Nacional de Abastecimento (2016) Política de garantia de preços mínimos para produtos da sociobiodiversidade. $2^{\mathrm{a}}$. ed. Cia. Nacional de Abastecimento, Brasília. 32p.

Conde BE, Ticktin T, Fonseca AS, Macedo AL, Orsi TO, Chedier LM, Rodrigues E \& Pimenta DS (2017) Local ecological knowledge and its relationship with biodiversity conservation among two quilombola groups living in the Atlantic Rainforest, Brazil. PLoS One 12: e0187599.

Contreras EJC, Medinaceli A, Diago OLS \& Villamar AA (2015) Código de ética para la investigación, la investigación-acción y la colaboración etnocientífica en América Latina Versión Dos. Etnobiología 13: 3-30.

Díaz S, Demissew S, Carabias J, Joly C, Lonsdale M, Ash N, Larigauderie A, Adhikari JR, Arico S, Báldi A, Bartuska A, Baste IA, Bilgin A, Brondizio E, Chan KMA, Figueroa VE, Duraiappah A, Fischer M, Hill R, Koetz T, Leadley P, Lyver P, Mace GM, Martin-Lopez B, Okumura M, Pacheco D, Pascual U, Pérez ES, Reyers B, Roth E, Saito O, Scholes RJ, Sharma N, Tallis H, Thaman R, Watson R, Yahara T, Hamid ZA, Akosim C, Al-Hafedh Y, Allahverdiyev R, Amankwah E, Asah TS, Asfaw Z, Bartus G, Brooks AL, Caillaux J, Dalle G, Darnaedi D, Driver A, Erpul G, Escobar-Eyzaguirre P, Failler P, Fouda AMM, Fu B, Gundimeda H, Hashimoto S, Homer F, Lavorel S, Lichtenstein G, Mala WA, Mandivenyi W, Matczak P, Mbizvo C, Mehrdadi M, Metzger JP, Mikissa JB, Moller H, Mooney HA, Mumby P, Nagendra H, Nesshover C, OtengYeboah AA, Pataki G, Roué M, Rubis J, Schultz M, Smith P, Sumaila R, Takeuchi K, Thomas S, Verma M, Yeo-Chang Y \& Zlatanova D (2015) The IPBES Conceptual Framework - connecting nature and people. Current Opinion in Environmental Sustainability 14: 1-16.

Finer M, Jenkins CN, Sky MAB \& Pine J (2014) Logging concessions enable illegal logging crisis in the peruvian amazon. Scientific Reports 4: article 4719

Flora do Brasil 2020 [em construção] Jardim Botânico do Rio de Janeiro. Available at $<$ http://floradobrasil. jbrj.gov.br/ >. Access on 27 March 2018.

Fonseca-Kruel VS, Silva IM \& Pinheiro CUB (2005) O ensino acadêmico da etnobotânica no Brasil. Rodriguésia 56: 97-106.

Forzza R, Carvalho Jr. A, Andrade ACS, Franco L, Estevão LA, Fonseca-Kruel VS, Coelho MN, Tamaio N \& Zappi D (2016) Coleções biológicas do Jardim Botânico do Rio de Janeiro à luz das metas da GSPC/CDB: onde estaremos em 2020? Museologia \& Interdisciplinaridade 5: 136-159.
Free CM, Matthew Landis R, Grogan J, Schulze MD, Lentini M \& Dünisch O (2014) Management implications of long-term tree growth and mortality rates: A modeling study of big-leaf mahogany (Swietenia macrophylla) in the Brazilian Amazon. Forest Ecology and Management 330: 46-54.

Fundação Cultural Palmares (2018) Comunidades Remanescentes de Quilombos. Available at $<$ http://www.palmares.gov.br/comunidadesremanescentes-de-quilombos-crqs $>$. Access on 2 julho 2018.

Gadgil M (2006)Ecology is for the people: a methodology manual for people's biodiversity register. Centre for Ecological Sciences/Indian Institute of Science, Bangalore. 233p.

Gaoue OG, Coe MA, Bond M, Hart G, Seyler BC \& McMillen H (2017) Theories and major hypotheses in ethnobotany. Economic Botany 71: 269-287.

GDF - Global Diversity Foundation (2018) Global Diversity Foundation: a world of difference. Available at $<$ https://www.global-diversity.org/>. Access on 27 março 2018.

Godoy RA \& Bawa K (1993) The economic value and sustainable harvest of plants and animals from the tropical forest: assumptions, hypotheses and methods. Economic Botany 47: 215-219.

Greenpeace, IMAFLORA, IMAZON, Instituto Centro de Vida, Instituto Socioambiental, IPAM, The Nature Conservancy, WWF (2017) A pathway to zero deforestation in the Brazilian Amazon. Available at $<$ http://ipam.org.br/wp-content/uploads/2017/11/APathway-to-Zero-Deforestation-in-the-BrazilianAmazon-full-report.pdf>. Access on 2 July 2018.

Grogan J \& Loveless MD (2013) Flowering phenology and its implications for management of big-leaf mahogany Swietenia macrophylla in Brazilian Amazonia. American Journal of Botany 100: 2293-2305.

Guariguata MR, Cronkleton P, Duchelle AE \& Zuidema PA (2017) Revisiting the 'cornerstone of Amazonian conservation': a socioecological assessment of Brazil nut exploitation. Biodiversity and Conservation 26: 2007-2027.

Guariguata MR, García-Fernández C, Sheil D, Nasi R, Herrero-Jáuregui C, Cronkleton P \& Ingram V (2010) Compatibility of timber and non-timber forest product management in natural tropical forests: perspectives, challenges, and opportunities. Forest Ecology and Management 259: 237-245.

Herraiz AD, Graça PMLDA \& Fearnside PM (2017) Amazonian flood impacts on managed Brazilnut stands along Brazil's Madeira river: a sustainable forest management system threatened by climate change. Forest Ecology and Management 406: 46-52.

IBGE - Instituto Brasileiro de Geografia e Estatística (2015) Produção da extração vegetal e da silvicutura. PEVS 30: 1-46. 
IPBES - Intergovernmental Science-Policy Platform on Biodiversity and Ecosystem Services (2018) Indigenous and local knowledge in IPBES. Available at $<$ https://www.ipbes.net/about $>$ Access on 11 April 2018.

ISA - Instituto Socioambiental (2018) Povos indígenas no Brasil. Available at $<$ https://pib.socioambiental. org/pt/L\%C3\%ADnguas $>$. Access on 2 July 2018.

ISE - International Society of Ethnobiology (2006) ISE Code of Ethics (with 2008 additions). Available at $<$ http://ise.arts.ubc.ca/global_coalition/ethics.php $>$. Access on 11 April 2018.

Kohler F \& Brondizio ES (2017) Considering the needs of indigenous and local populations in conservation programs. Conservation Biology 31: 245-251.

Krupnick GA (2013) Conservation of tropical plant biodiversity: what have we done, where are we going? Biotropica 45: 693-708.

Lagos-Witte S, Diago OLS, Chacón P \& García R (2012) Manual de herramientas etnobotánicas relativas a la conservación y el uso sostenible de los recursos vegetales. Una contribución de la Red Latinoamericana de Botánica a la implementación de la Estrategia Global para la Conservación de las Especies Vegetales hacia el logro de las Metas 13 y 15. Red Latinoamericana de Botánica, Santiago. 138p.

Liporacci SNL, Miranda TM, Hanazaki N \& Peroni N (2015) How are legal matters related to the access of traditional knowledge being considered in the scope of ethnobotany publications in Brazil? Acta Botanica Brasilica 29: 251-261.

Machado Mello AJ \& Peroni N (2015) Cultural landscapes of the araucaria forests in the northern plateau of Santa Catarina, Brazil. Journal of Ethnobiology and Ethnomedicine 11: 51.

Martins E, Loyola R \& Martinelli G (2017) Challenges and perspectives for achieving the global strategy for plant conservation targets in Brazil. Annals of the Missouri Botanical Garden 102: 347-356.

Missouri Botanical Garden (2018) About the William L. Brown Center. Available at $<$ http://www. missouribotanicalgarden.org/plant-science/plantscience/william-l-brown-center/about-wlbc.aspx>. Access on 11 April 2018.

MMA-Ministério do Meio Ambiente (2011) Chamamento Público para fortalecimento da gestão florestal estadual para implementação do Programa Mais Ambiente, 002/2011. Secretaria de Extrativismo e Desenvolvimento Rural Sustentável. Available at $<$ http://www.mma.gov.br/estruturas/170/ ECAP/170 ecap29092011050429.pdf>. Access on 28 March 2018.

Moreira ECP \& Conde LB (2017) A lei N. 13.123/2015 e o retrocesso na proteção dos conhecimentos tradicionais. Veredas do Direito 14: 715-205.
Oliveira FC, Albuquerque UP, Fonseca-Kruel VS \& Hanazaki N (2009) Avanços nas pesquisas etnobotânicas no Brasil. Acta Botanica Brasilica 23: 590-605.

Pedrollo CT \& Kinupp VF (2015) Sustainability or colonialism? Legislative obstacles to research and development of natural products and patents on traditional knowledge in Brazil. Acta Botanica Brasilica 29: 452-456.

Peres CA, Baider C, Zuidema PA, Wadt LHO, Kainer KA, Gomes-Silva DAP, Salomão RP, Simões LL, Franciosi ERN, Valverde FC, Gribel R, Shepard Jr. GH, Kanashiro M, Coventry P, Yu DW, Watkinson AR \& Freckleton RP (2003) Demographic threats to the sustainability of Brazil nut exploitation. Science 302: 2112-2114.

Prathapan KD, Pethiyagoda R, Bawa KS, Raven PH, Rajan PD \& et al. (2018) When the cure kills CBD limits biodiversity research. Science 360: 1405-1406.

Rêgo JL \& Andrade MP (2006) História de Mulheres: breve comentário sobre o território e a identidade das quebradeiras de coco babaçu no Maranhão. Agrária 3: 47-57.

Ribeiro MBN, Jerozolimski A, de Robert P \& Magnusson WE (2014) Brazil nut stock and harvesting at different spatial scales in southeastern Amazonia. Forest Ecology and Management 319: 67-74.

Rist L, Shanley P, Sunderland T, Sheil D, Ndoye O, Liswanti N \& Tieguhong J (2012) The impacts of selective logging on non-timber forest products of livelihood importance. Forest Ecology and Management 268: 57-69.

Saha D \& Sundriyal RC (2012) Extraction of non timber forest products in humid tropics: consumption pattern, contribution to rural income and forest revenue. Forest Policy and Economics 14: 28-40.

Schmidt IB \& Ticktin T (2012) When predictions from matrix population models and local ecological knowledge coincide: Effects of flower stalk harvest on populations of an economically important nontimber forest product (NTFP) in the Brazilian savanna. Biological Conservation 152: 187-195.

Schmidt IB, Mandle L, Ticktin T \& Gaoue OG (2011) What do matrix population models reveal about the sustainability of non-timber forest product harvest? Journal of Applied Ecology 48: 815-826.

Schöngart J (2008) Growth-Oriented Logging (GOL): a new concept towards sustainable forest management in Central Amazonian várzea floodplains. Forest Ecology and Management 256: 46-58.

Sharrock S \& Jackson PW (2017) Plant conservation and the sustainable development goals: a policy paper prepared for the global partnership for plant 
conservation. Annals of the Missouri Botanical Garden 102: 290-302.

Silva-Marinho TA, Piedade MTF \& Wittmann F (2010) Distribution and population structure of four Central Amazonian high-várzea timber species. Wetlands Ecology and Management 18: 665-677.

Simoni J, Sawyer DR \& Almeida FVR (2010) Entraves regulatórios na produção agroextrativista. ISPN 98p.

Sobral M \& Stehmann JR (2009) An analysis of new angiosperm species discoveries in Brazil (1990-2006). Taxon 58: 227-32.

Solecki W, Brondizio ES \& Leemans R (2016) Editorial overview: open issue, part I: a new era of global environmental sustainability understanding. Current Opinion in Environmental Sustainability 23: iv-vi.

Souza AF, Cortez LSR \& Longhi SJ (2012) Native forest management in subtropical South America: Longterm effects of logging and multiple-use on forest structure and diversity. Biodiversity and Conservation 21: 1953-1969.

Stanley D, Voeks R \& Short L (2012) Is non-timber forest product harvest sustainable in the less developed world? A systematic review of the recent economic and ecological literature. Ethnobiology and Conservation 1. DOI: 10.15451/ec2012-8-1.9-1-39.

Swiderska K, Argumedo A, Song Y, Li J, Pant R, Herrera H, Mutta D, Munyi P \& Vedavathy S (2009) Protecting community rights over traditional knowledge: implications of customary laws and practices. Key findings and recommendations 2005-2009. Available at $<$ http://pubs.iied.org/pdfs/14591IIED.pdf $>$. Access on 11 April 2018.

Teixido AL, Toorop PE, Liu U, Ribeiro GVT, Fuzessy LF, Guerra TJ \& Silveira AO (2017) Gaps in seed banking are compromising the GSPC's Target 8 in a megadiverse country. Biodiversity and Conservation 26: 703-716.

Tengo M, Hill R, Malmer P, Raymond CM, Spierenburg M, Danielsen F, Elmqvist T \& Folke C (2017) Weaving knowledge systems in IPBES, CBD and beyondlessons learned for sustainability. Current Opinion in Environmental Sustainability 26: 17-25.

Ticktin T (2004) The ecological implications of harvesting non-timber forest products. Journal of Applied Ecology 41: 11-21.

Ulian T, Sacandé M, Hudson A \& Mattana E (2017) Conservation of indigenous plants to support community livelihoods: the MGU-Useful Plants Project. Journal of Environmental Planning and Management 60: 668-683.

UNEP/UNESCO (2002) Cultural diversity and biodiversity for sustainable development. High Level Roundtable, Johannesburg. Available at $<$ http://unesdoc.unesco. org/images/0013/001322/132262e.pdf $>$. Access on 11 April 2018.

Vidal E, West TAP \& Putz FE (2016) Recovery of biomass and merchantable timber volumes twenty years after conventional and reduced-impact logging in Amazonian Brazil. Forest Ecology and Management 376: 1-8. 